\title{
Üniversite Öğrencilerinin Uzaktan Eğitim Memnuniyeti Ölçeği'nin Geliştirilmesi: Geçerlik ve Güvenirlik Çalışması
}

\author{
Development of Distance Education Satisfaction Scale of University Students: Validity and \\ Reliability Study
}

\author{
Ali Yasin Kafes* - Ahmet Yıldırım**
}

\begin{abstract}
This research aims to develop a scale that measures students' satisfaction regarding the comprehensive distance education application that universities have quickly implemented within the scope of the Covid-19 pandemic. The scale is based on interaction and communication theory in education. According to the theory, it is stated that in the process of distance education, the existence of factors such as enjoying learning, ensuring interaction, making learning simpler, motivation and transferring what has been learned, and these factors trigger each other, learning will be easier. An application was made to the Ethics Committee of Süleyman Demirel University on 05.03.2021 for the ethical review of the study. With the decision numbered E-87432956-050.99-33128 on 11.03.2021, ethical committee approval was obtained for the scientific study.The study was carried out with the voluntary participation of 3664 students studying at Isparta Süleyman Demirel University in the 2020-2021 Academic Year. The questions prepared were conveyed to the participants via the internet. SPSS 25.0 and LISREL 8.80 programs were used for statistical processes. Expert opinions were received within the scope of the validity studies of the scale, and EFA and CFA were applied. Accordingly, the scale explained $63.04 \%$ of the variance in total. The items "affected" as predicted and were collected in equal numbers under the "availability" factors. The goodness of fit values of the scale was found to be quite good. Within the scope of reliability studies, Cronbach Alpha, test halving, and test-retest applications were performed. According to the results obtained, the scale is reliable. To determine the distinctiveness of the items in the scale, $27 \%$ lower-upper group comparisons with item-total correlation corrected with both their factors and the whole scale were included. Findings obtained from item analysis showed that all of the items in the scale were distinctive. Based on these findings, it can be said that UOUEMÖ is a valid and reliable measurement tool and can be used to measure students' satisfaction with distance education.
\end{abstract}

Structured Abstract: Satisfaction of university students with their educational processes can be considered as an important criterion in determining the quality of their education. However, the degree of satisfaction of

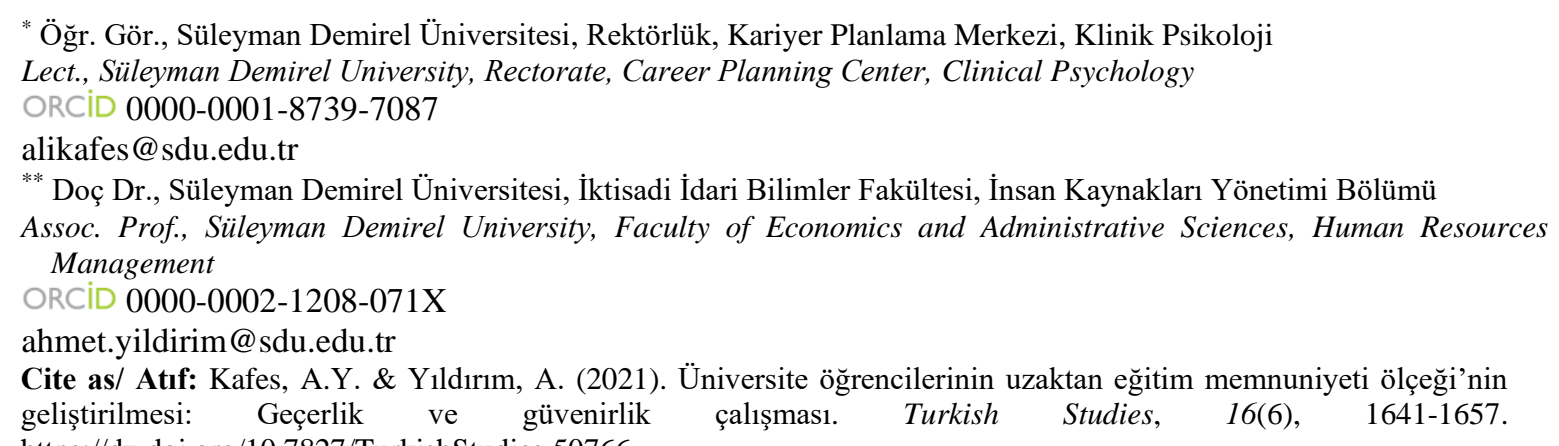
https://dx.doi.org/10.7827/TurkishStudies.50766

Received/Geliş: 06 April/Nisan 2021

Accepted/Kabul: 25 December/Aralık 2021

Published/Yayın: 30 December/Aralık 2021 
students with their university education has a high impact on the graduate rate of universities. It is argued that considering the satisfaction, expectations, and wishes of university students based on the quality of the education they receive by universities will provide different strategic opportunities for universities. It has become vitally important in terms of their ontological position that they develop strategies that take into account and construct themselves within this framework. In this context, since 2015, measurement of student satisfaction has been used as an important data source for quality assessment and strategic planning for universities. In distance education and according to communication theory, distance education is stated to be easier to learn by triggering factors such as making learning more enjoyable than learning, simplifying learning, motivation, and transferring what has been learned. In other words, according to this theory, it will determine the satisfaction of taking the right steps in distance education centered on communication and interaction. Kocadere (2013) evaluated the factors affecting student satisfaction in distance education under three headings, educational, administrative, and individual. Instructional design and usability in educational dimension; In the administrative dimension, admission student affairs, support, student orientation, and cost and individual dimensions included teacher and learner sub-dimensions. According to Kocadere (2013), the teacher sub-dimension is about behaviors close to students and attitude towards e-learning; The student subdimension includes computer skills, demographic characteristics, learning self-efficacy, autonomous learning style, personal interest, and interaction skills. In the model developed about student satisfaction in asynchronous e-systems, I examined student satisfaction in four dimensions: student interface, learning society, content, and personal behavior. It is seen that Kantoğlu et al. (2013) developed a five-dimensional scale for e-learning. This study; Based on communication and interaction theory, the satisfaction scale of university students towards distance education is structured to measure the satisfaction of university students towards distance education in a process where competition becomes global and distance education experience becomes a necessity rather than differentiation. Method: An application was made to the Ethics Committee of Suleyman Demirel University on 05.03.2021 for the ethical review of the study. On 11.03.2021, the ethics committee received scientific study approval with the decision numbered E-87432956050.99-33128. The research was conducted with a volunteer participant group of 3664 people who continued their education at Süleyman Demirel University in Isparta in the 2020-2021 Academic Year and answered all of the items. Students studying in 26 of a total of 28 vocational colleges/faculties/institutes/conservatories within the university participated in the research. 1298 (35.2\%) of the participants are male and $2366(64.3 \%)$ are female. Developing the Scale Form: The Distance Education Satisfaction Scale of University Students (UÖUEMÖ) was created from an item pool of 30 questions for university students. Due to various reasons, items were removed and the scale was reduced to 8 items. There is no reverse article among the mentioned 8 items. During the study, SPSS 25.0 was used for reliability, EFA, lower-upper group mean difference studies, and LISREL 8.80 programs were used for the CFA study. Results: As a result of EFA, it was determined that the items were divided into two factors under the theoretical studies and the items were equally distributed to both factors. Factors explained $63.03 \%$ of the total variance. The first factor, the interaction factor, explained $32.63 \%$, and the second factor, the accessibility factor, explained $30.40 \%$. The factor loads of the items in the interaction dimension ranged from .82 to .73 , and the factor loads of the items in the accessibility dimension ranged from .78 to .65 . Considering the difference between the $27 \%$ sub-upper group mean scores, it was concluded that the questions differentiated the satisfaction levels and each question made appropriate measurements for the participant levels. CFA study was carried out with the second half of the participants. In line with the study, it was tested whether the structure consisting of 8 items and two factors obtained as a result of EFA could be verified or not. During the analysis, the error terms of the 3rd and 2nd items, 1 st and 4 th items belonging to the interaction dimension, and the 2nd and 1 st items belonging to the accessibility dimension were respectively linked. The data obtained reveal that the goodness of fit values of the scale with the two-factor model is quite good. When we examine the reliabilty analysis results, we can say that the Cronbach Alpha value of the overall scale and interaction dimension above .80 in the general sample data is highly reliable, and the accessibility dimension close to .80 is close to high reliability. The test half-way method was used to obtain other reliability proofs of the internal consistency of the test, and the test half-way technique was used to obtain evidence of its stability. Guttman's formula was used in the calculation of the reliability coefficient because the variance of the halves was not equal when applying the test halving method. Accordingly, the reliability coefficient was calculated as 0.87 . Test-retest results were also highly reliable in parallel. Discussion: When the Turkish literature is examined, a limited number of studies have been identified that can be used to measure satisfaction with distance education. There is no scale developed based on communication and interaction theory in distance education. This study, in which the development of UÖUEMÖ is aimed, is important in that it will fill the aforementioned gap in the literature. In other words, 
one of the strengths of the study about satisfaction with distance education based on interaction and communication is that it provides a step in the Turkish literature on the subject. Providing more than one evidence about the distinctiveness, validity, and reliability of the scale items of the measurements obtained from the UOUEMÖ is among the strengths of the study. In addition to the strengths of the study, there are also a number of teams. The most important information of the study is only in the sample of the university. It is important to conduct future studies on different samples. Another thing is, when the literature is examined, the realization of interaction and communication theory, individual, educational, and managerial aspects of satisfaction can be developed.

Keywords: Psychometry, distance education, satisfaction, university students, validity, reliability, scale, development

Öz: $\mathrm{Bu}$ araştırma, özellikle Covid-19 pandemisi kapsamında üniversitelerin hızlı bir şekilde uygulamaya geçirdiği kapsamlı uzaktan eğitim uygulaması hakkında öğrencilerin memnuniyetini ölçen bir ölçeği geliştirmeyi amaçlamaktadır. Ölçek eğitimde etkileşim ve iletişim teorisine dayandırılmıştır. Teoriye göre, uzaktan eğitim sürecinde iletişimin temelinde öğrenmeden keyif alınması, etkileşimin sağlanması, öğrenmeyi daha basit hale getirme, motivasyon ve öğrenilenlerin transfer edilmesi gibi faktörlerin varlığı ve bu faktörlerin birbirlerini tetiklemesiyle öğrenmenin kolaylaşacağı belirtilmektedir. Çalışmanın etik incelemesi için Süleyman Demirel Üniversitesi Etik Kurulu'na 05.03.2021 tarihinde başvuru yapılmıştır. 11.03.2021 tarihinde E-87432956-050.99-33128 sayılı karar ile etik kurul bilimsel çalışma onayı alınmıștır. Çalışma 2020-2021 Eğitim-Öğretim Y1lı içerisinde Isparta Süleyman Demirel Üniversitesi’nde eğitim gören 3664 öğrencinin gönüllü katılımıyla gerçekleştirilmiştir. Hazırlanan sorular katılımcılara internet aracılığg ile iletilmiştir. İstatistiksel işlemler için SPSS 25.0 ve LISREL 8.80 programları kullanılmıştır. Ölçeğin geçerlik çalışmaları kapsamında uzman görüşleri alınmış, AFA ve DFA uygulaması yapılmıştır. Buna göre ölçek varyansın toplamda \%63.04'ünü açıklamıştır. Maddeler tahmin edildiği gibi "etkilemiş" ve "ulaşılabilirlik" faktörleri altında eşit sayıda toplanmıştır. Ölçeğin uyum iyiliği değerleri oldukça iyi bulunmuştur. Güvenirlik çalışmaları kapsamında ise Cronbach Alfa, test yarılama ve test tekrar test uygulamaları yapılmıştır. Elde edilen sonuçlara göre ölçek güvenilirdir. Ölçekteki maddelerin ayırt ediciliğini belirlemek amacıyla maddelerin hem kendi faktörleri ile hem de ölçeğin bütünü ile düzeltilmiş madde toplam korelasyonu ile \%27'lik alt-üst grup karşılaştırmalarına yer verilmiştir. Madde analizinden elde edilen bulgular, ölçekte yer alan maddelerin tamamının ayırt edici olduğunu göstermiştir. Bu bulgulara dayanarak Üniversite Öğrencilerinin Uzaktan Eğitim Memnuniyet Ölçeği’nin (ÜÖUEMÖ) geçerli ve güvenilir bir ölçme arac1 olduğu ve öğrencilerin uzaktan eğitimden memnuniyetlerini ölçmek amacı ile kullanılabileceği söylenebilir.

Anahtar Kelimeler: Psikometri, uzaktan eğitim, memnuniyet, üniversite öğrencileri, geçerlik, güvenirlik, ölçek, geliştirme

\section{Giriş}

Üniversite öğrencilerinin eğitim süreçlerinden memnuniyeti, aldıkları eğitiminin niteliğini belirleme açısından önemli kriter olarak değerlendirilebilir. Bununla birlikte öğrencilerin üniversite eğitimlerine yönelik memnuniyet düzeylerinin derecesi, üniversitelerin mezuniyet oranlarına yüksek oranda etki etmektedir (Student Life Studies, 1999). Üniversite öğrencilerinin aldıkları eğitimin niteliğine dayalı memnuniyetleri, beklenti ve isteklerinin üniversiteler tarafindan dikkate alınmasının üniversitelere stratejik anlamda farklı imkanlar sağlayacağı savunulmaktadır (Elliot \& Shin 2002, s. 197-209) Bu bağlamda üniversitelerin durumsallıkları, amaç ve vizyonları dahilinde karşı karşıya kaldıkları fiili durumlara ve geleceğe dair karşılaşacakları risklere karşın öğrencilerin memnuniyetini dikkate alan stratejiler geliştirmeleri ve bu çerçevede kendilerini yapılandırmaları, ontolojik konumları açısından hayati derece de önemli hale gelmiştir. Bu çerçevede 2015'ten itibaren üniversiteler açısından öğrenci memnuniyetinin ölçülmesi kalite değerlendirmesi ve stratejik planlama için önemli veri kaynağı olarak kullanılmaya başlanmıştır (Şimşek vd., 2019, s. $383)$. 
"Bireylerin beklentileri ile mal veyahut hizmetten algıladıkları performans arasındaki ilişkidir." şeklinde tanımlanan (Aktepe vd., 2009, s. 8) memnuniyet kavramı, sunulan hizmete ilişkin tepkinin sağliklı göstergelerinden birisi olarak değerlendirilmektedir. Bu ön kabule bağlı olarak 1950'lerden itibaren çeşitli kurumlar, verdikleri hizmetin bireylerin memnuniyet seviyesini belirlemek gayesiyle bazı ölçümler yapmaya başlamışlardır. Günümüzde her alanda giderek küreselleşen rekabet, yükseköğretim kurumlarını etkisi altına alan en önemli unsurlardan birisi haline gelmiştir. Küresel rekabet, yalnızca ulusal düzeyde değil aynı zamanda uluslararası düzeyde de, kurumsal performanslarını arttırmada ve başka üniversitelerle yarışır hale gelmelerinde üniversiteler üzerinde güçlü bir bask1 faktörü haline gelmiştir.

Üniversiteler yakın zamanda ürün ve hizmetlerinin yararlanıcısı veya alıcısı konumundaki grupları eskisinden daha fazla dikkate almışlardır (Srikanthan \& Dalrymple, 2002, s. 218). Bu gruplardan en önemlileri üniversitelerin mevcut öğrencileri ve gelecekteki olas1 öğrencileridir. Ansari (2002) öğretme ve öğrenme faaliyetlerinin ölçülmesinde faaliyetlerin niteliğinin en önemli göstergelerinden birisinin öğrenci memnuniyeti olduğunu düşünmektedir. $\mathrm{Bu}$ bağlamda yükseköğretim kurumlarının ve faaliyetlerinin planlı, amaca yönelik, kontrollü, tertipli ve gelişigüzellikten uzak bir şekilde düzenlenmesi, öğretme ve öğrenme faaliyetlerini başarılı ve etkili k1larken öğrencilerin memnuniyet seviyelerini de arttıracaktır (Oğuz, 2002, s. 19). Yükseköğretim kurumlarının sundukları hizmetin kalitesinin artırılmasında, hizmetin alıcısı kabul edilen öğrenciler için uygun koşulların oluşturulması ve beklentilerinin belirlenmesi oldukça önem arz etmektedir (Baykal vd., 2002, s. 25). Yükseköğretim kurumlarında öğrencilerin memnuniyet düzeylerinin saptanabilmesi, eğitim standardının yükselmesi, yeni kaynakların bulunması ve buna bağlı olarak eğitimde yenileşme açısından önemlidir (Baykal \& Şahin, 1999, s. 127). Genel manada üniversite öğrencilerinin memnuniyetlerini etkileyen birçok faktörün varlı̆̆ından bahsedebiliriz. Bu faktörler yönetim, akademik ve öğretim araç ve gereçleri (Erdoğan \& Uşak, 2005, Tütüncü \& İpekgilDoğan, 2003; Ulusoy vd., 2010; Wilson \& Gaff, 1975), kampüs yaşam1, yönlendirme-rehberlik, sosyo-kültürel olanaklar, öğrenciye gösterilen değer, öğrencilerin düşüncelerinin, isteklerinin idari süreçlere dahil edilmesi ile araştırma olanakları (Erdoğan \& Uşak, 2004; Ulusoy vd., 2010) olarak ifade edilebilir (Gatfield vd., 1999, s. 244). Öğrenciler zamanlarının büyük bir kısmını üniversitelerin kampüsleri içerisinde akademik personel ve kendi arkadaşları ile geçirmektedirler. Bu bağlamda Lamport (1993), Wilson ve Gaff (1975) üniversite akademik personelinin ve arkadaş gruplarının öğrencilerin memnuniyetleri üzerinde büyük bir etkisi olduğunu iddia etmektedirler.

Öğrencilerin üniversitenin kendilerine sunduğu eğitim hizmetlerine yönelik görüşleri bir önceki paragrafta sıralanan boyutlara ilişsin niteliği sorgulayan "öğrenci memnuniyeti" araştırmaları yoluyla tespit edilmektedir. Öğrenci memnuniyeti araştırmalarının eğitim süreciyle ilgili kısmı ise öğrenmenin, çok kuvvetli bir şekilde dersten sağlanan doyumla ilgili olduğunu bildirmektedir (Guolla, 1999, s. 87). Bu sebeple öğrencilerin eğitim sürecine yönelik beklentilerini anlamak, eğitim sürecine ilişkin memnuniyetlerini sağlamada ve değerlendirmede önemli bir hale gelmektedir. Öğreten ve öğrenen aktörlerin farklı mekanlarda olduğu, planlı öğrenme ortamında öğrencilere basılı veya elektronik iletişim yöntemleri vesilesiyle öğretimin sunulduğu tüm düzenlemeleri içeren bir boyutta anlam içeren uzaktan eğitim günümüz şartlarında önemli bir deneyim sürecindedir. Yükseköğrenim düzeyinde uzaktan eğitimin olgusal gerçekliği, bir eğitimöğretim alternatifi boyutundan çok daha büyük anlamlar içerecek şekilde dönüşmüştür. Yükseköğretim hizmetinin ikame edilebilir boyutu içerisinde fark yaratıcı bir boyutundan ziyade, küresel pandemi sürecinde zorunlu bir hale gelen uzaktan eğitim, sürecin kendisiyle beraber çıktılarını da öğrenci memnuniyeti bağlamında irdelemeyi küresel rekabet sürecinde zorunlu kılmaktadır. Uzaktan eğitimin başarısına etki eden bir hayli faktörün varlığından bahsedilmektedir. Memnuniyet ise bu unsurların içinde önemli bir yere sahip olanıdır. Tessema ve arkadaşları (2012) eğitim programının etkililiğini sınavlar, proje ve sunumlar gibi doğrudan performans ölçümleriyle, öğrenci memnuniyeti gibi boyutlarla dolaylı performans ölçümleriyle değerlendirilebilmektedir. 
Nitelikli insan yetiştirme sürecinde uzaktan eğitimin kalitesinin arttırılması kaçınılmazdır. Temelde Covid 19 Pandemisinin ortaya çıkardığ 1 travmatik bir kırılmaya bağlı ikame edilen uzaktan eğitim kanallarının, bu süreçte ortaya çıkardığ 1 firsatlar ve avantajları uzaktan eğitim olgusunun alternatif bir eğitim mecrasından ziyade vazgeçilmez bir anlam bütünlüğüne dönüştüğü ortadadır. Ancak uzaktan eğitimin çıktıları açısından riskleri ve çözümsüzlük alanlarının da değerlendirilmeye mukim olduğu gözden kaçırılmamalıdır. Bu bağlamda uzaktan eğitimin hem nesnesi hem de öznesi konumundaki üniversite öğrencilerinin kendilerine sunulan eğitime dair memnuniyet seviyesi üniversitelerin performanslarının değerlendirilmesi kadar, eğitime yüklenilen anlama bağlı olarak toplumsal beklentilerin karşılı̆̆ 1 da tartışmalı hale gelebilir.

Alanyazında uzaktan eğitimde öğrencilerin memnuniyetini etkileyen en önemli unsurların başında öğrencinin bilgisayar kaygısı, uzaktan eğitime karşı eğitmenin tutumu, uzaktan eğitim dersinin esnekliği, algılanan fayda, uzaktan eğitimin kalitesi, değerlendirmelerdeki çeşitlilik ve algılanan kullanım kolaylığının olduğu vurgulanmaktadır (Sun vd., 2008, s. 1187). Uzaktan eğitimde iletişim ve etkileşim kuramına göre uzaktan eğitim sürecinde iletişimin temelinde öğrenmeden keyif alınması, etkileşimin sağlanması, öğrenmeyi daha basit hale getirme, motivasyon ve öğrenilenlerin transfer edilmesi gibi faktörlerin varlığı ve bu faktörlerin birbirlerini tetiklemesiyle öğrenmenin kolaylaşacağ 1 belirtilmektedir (Gökmen vd., 2016, s. 35). Diğer bir ifadeyle bu kurama göre uzaktan eğitimde iletişim ve etkileşim merkezli doğru adımların atılması öğrencilerin memnuniyetini de belirleyecektir. Kocadere (2013) uzaktan eğitimde öğrenci memnuniyetine etkisi olan unsurları eğitsel, yönetsel ve bireysel olarak üç başlık altında değerlendirmiştir. Eğitsel boyutta öğretim tasarımı ve kullanılabilirlik; yönetsel boyutta, çevrimiçi öğrenci işleri, destek, öğrenci oryantasyonunu ve maliyet ve bireysel boyut ise öğretmen ve öğrenen alt boyutlarına yer vermiştir. Kocadere (2013)'ye göre öğretmen alt boyutu öğrencilere yönelik yakın davranışlar ve e-öğrenmeye yönelik tutum; öğrenci alt boyutu ise bilgisayar becerileri, demografik özellikler, çevrimiçi öğrenme öz yeterliği, özerk öğrenme tarzı, bireysel ilgi ve etkileşim becerilerini kapsamaktadır. Asenkron e-öğrenme sistemlerinde öğrenci memnuniyeti ile ilgili olarak geliştirdiği modelde, öğrenci arayüzü, öğrenme toplumu, içerik ve kişisel davranışlar olmak üzere öğrenci memnuniyetini dört boyutta incelemiştir. Kantoğlu ve arkadaşları (2013), e-öğrenmeye yönelik beş boyutlu bir ölçek geliştirdikleri görülmektedir.

$\mathrm{Bu}$ çalışmada; üniversite öğrencilerinin uzaktan eğitime yönelik memnuniyet düzeylerini değerlendiren iletişim ve etkileşim kuramına dayalı bir ölçme aracının geliştirilmesi amaçlanmaktadır.

\section{Yöntem}

Çalışmanın etik incelemesi için Süleyman Demirel Üniversitesi Etik Kurulu'na 05.03.2021 tarihinde başvuru yapılmıştır. 11.03.2021 tarihinde E-87432956-050.99-33128 sayılı karar ile etik kurul bilimsel çalışma onayı alınmıştır.

\section{Çalışma Grubu}

Araştırma, 2020-2021 Eğitim-Öğretim Yılı içerisinde Isparta'da Süleyman Demirel Üniversitesi'nde eğitimini devam ettiren ve maddelerin hepsini cevaplamış olan 3664 kişilik gönüllü katılımcı grubu ile yapılmıştır. Araştırmaya üniversite bünyesindeki toplam 28 meslek yüksekokulu, fakülte, enstitü, konservatuarın 26'sında eğitim gören öğrenciler katılmıştır. Örneklem amaçsal ve teorik örneklem seçimi yöntemi ile belirlenmiştir. Bu yöntem ölçek geliştirme çalışmaları için uygun bir yöntemdir (Kümbetoğlu, 2012). Katılımcıların 1298'i (\%35.2) erkek, 2366'sı (\%64.3) kadındır. Geçerlik çalışmaları kapsamında veriler açımlayıcı (AFA) ve doğrulayıcı (DFA) faktör analizleri yapılabilmesi adına yarıdan ikiye bölünmüştür. Buna göre AFA için 1832 katılımcı, DFA için 1831 katılımcının verileri kullanılmıştır. Katılımcılara ilişkin diğer bilgiler ise tabloda belirtilmiştir (Tablo 1). 
Tablo 1: Geçerlik Çalışması Yapılan Katılımcılara Dair Demografik Bilgiler

\begin{tabular}{|c|c|c|c|c|c|c|}
\hline \multicolumn{7}{|c|}{ GEÇERLIK } \\
\hline & & AFA & & & DFA & \\
\hline & $\mathbf{N}$ & $\%$ & Yaş (SS) & $\mathbf{N}$ & $\%$ & Yaş (SS) \\
\hline Kadın & 1235 & 67.5 & $\begin{array}{l}20.34 \\
(2.23)\end{array}$ & 1130 & 61.8 & $\begin{array}{l}20.62 \\
(2.29)\end{array}$ \\
\hline Erkek & 597 & 37.5 & $\begin{array}{l}21.25 \\
(2.50)\end{array}$ & 701 & 38.2 & $\begin{array}{l}21.34 \\
(2.70)\end{array}$ \\
\hline Toplam & 1832 & 100 & $\begin{array}{l}20.63 \\
(2.35)\end{array}$ & 1831 & 100 & $\begin{array}{l}20.89 \\
(2.47)\end{array}$ \\
\hline
\end{tabular}

Güvenirlik çalışmaları kapsamında ise tüm katılımcı verileri ile Cronbach Alfa ve test yarılama yöntemleri ile güvenirlik çalışmaları yapılmıştır. Bu analizin katılımcılarına ilişkin diğer bilgiler ise tabloda belirtilmiştir (Tablo 2).

Tablo 2: Güvenirlik Çalışması Yapılan Katılımcılara Dair Demografik Bilgiler (Tüm Katılımcıları İçermektedir)

\section{GÜVENIRLIKK}

\begin{tabular}{|c|c|c|c|c|c|c|}
\hline & \multicolumn{3}{|c|}{$\begin{array}{l}\text { Cronbach Alfa ve } \\
\text { Test Yarılama }\end{array}$} & \multicolumn{3}{|c|}{ Test Tekrar Test } \\
\hline & $\mathbf{N}$ & $\%$ & Yaş (SS) & $\mathbf{N}$ & $\%$ & Yaş (SS) \\
\hline Kadın & 2366 & 64.5 & $\begin{array}{l}20.47 \\
(2.61)\end{array}$ & 218 & 65.1 & $\begin{array}{l}21.52 \\
(3.53)\end{array}$ \\
\hline Erkek & 1298 & 35.5 & $\begin{array}{l}21.30 \\
(2.62)\end{array}$ & 117 & 34.9 & $\begin{array}{l}22.32 \\
(2.39)\end{array}$ \\
\hline Toplam & 3664 & 100 & $\begin{array}{l}20.77 \\
(2.43)\end{array}$ & 335 & 100 & $\begin{array}{l}21.80 \\
(2.86)\end{array}$ \\
\hline
\end{tabular}

\section{Veri Toplama Araçları}

Ölçek Formunun Geliştirilmesi: Üniversite Öğrencilerinin Uzaktan Eğitim Memnuniyet Ölçeği (ÜÖUEMÖ) üniversite öğrencilerine yönelik 30 soruluk bir madde havuzundan oluşturulmuştur. $\mathrm{Bu}$ havuz oluşturulurken alanyazından elde edilen bulgulardan ve insan kaynakları, psikoloji, iletişim, kariyer planlama, ölçme ve değerlendirme ve Türkçe eğitimi uzmanlarından görüşler alınmıştır. Alanyazın doğrultusunda oluşturulan problem durumları uzmanlar tarafindan incelenmiş ve problemlerin uzaktan eğitim sürecinde etkileşim ve uzaktan eğitime ulaşılabilirlik alanlarına göre gruplandırılmıştır. Araştırmanın "Iş̧lem" başlığı altında belirtilen çeşitli sebeplerden dolayı maddeler çıkarılarak ölçek 8 maddeye indirilmiştir. Söz konusu 8 madde arasında ters madde bulunmamaktadır. Yine araştırmanın "İşlem" başlığı altında detayları anlatılan çeşitli nedenlerden dolayı ve ölçeğin alanyazın incelenmesi neticesinde iki boyuttan oluşmasının uygun olacağı öngörülmüştür. $\mathrm{Bu}$ boyutlar, etkileşim ve ulaşılabilirlik boyutlarıdır. Ölçeğin değerlendirilmesinde, alanyazındaki ölçek maddelerinin değerlendirilmesi 
göz önüne alınarak (Parlak, 2007; Yıldırım vd., 2014; Kışla, 2016) likert tipi puanlama yapılasına karar verilmiştir. Değerlendirme esnasında; söz konusu madde katılımcının düşüncesi ile hiç uyuşmuyorsa bir, kısmen uyuşuyorsa iki, kararsız ise üç, uyuşuyorsa dört ve tamamen uyuşuyorsa beş puan kullanılmaktadır. Örneğin; "Uzaktan eğitim süreci başarımı olumlu yönde etkiledi." şeklindeki maddeye cevap verirken katılımcı, uzaktan eğitimin başarısını olumlu yönde etkilemediğini düşünüyorsa bir, kısmen olumlu etkilediğini düşünüyorsa iki, bu konuda kararsızsa üç, olumlu yönde etkilediğini düşünüyorsa dört ve kesinlikle olumlu yönde etkilediğini düşünüyorsa beş puan verilmektedir.

\section{İșlem}

Çalışma sırasında güvenirlik, AFA, alt-üst grup ortalama farkı çalışmaları için SPSS 25.0, DFA çalışması için ise LISREL 8.80 programları kullanılmıştır.

30 soruluk problem maddeleri örneklemin özellikleri dikkate alınarak çeşitli uzmanlar tarafından tekrar gözden geçirilmiş ve 5 madde her iki gruba da ait olması, 6 madde her iki gruba da ait olmaması nedeniyle havuzdan çıkarılmıştır. Türkçe eğitimi uzmanı tavsiyesi ile 9 madde dil yapısına uygun olmadığı gerekçesi ile havuzdan çıkarılmıştır. Son olarak yapılan AFA neticesinde 1 maddenin faktör yükü. 30'un altında kalması ve 1 maddenin de her iki faktöre de yüklenmesi sonucu maddeler havuzdan çıkarılmıştır (Pallant, 2005; Büyüköztürk, 2010). Bu işlem neticesinde ölçeği oluşturan maddelerinin sayısı 8'e inmiştir.

Araştırmanın geçerlik ve güvenirlik çalışmaları yapılmıştır. Geçerlik kapsamında kapsam ve yapı geçerliği, güvenirlik kapsamında iç tutarlılık ve kararlılık incelemesi yapılmıştır. Kapsam geçerliğini sağlamak amacıyla alanyazın incelemesi yapılmış ve uzmanlar eşliğinde ölçme aracında yer alan sorular oluşturulmuştur. Ardından görüş alınması adına farklı uzmanlara gönderilmiştir. Katılımcılardan elde edilen verilerin faktör analizine uygunluğu Kaiser-MeyerOlkin (KMO) katsayısı ve Bartlett küresellik testi ile incelenmiştir. Bu aşamadan sonra geçerlik çalışmaları kapsamında AFA, madde toplam korelasyonları, alt üst grup ortalamalar fark1, DFA, hesaplanmıştır. Ölçeğin güvenirlik çalışmasında ise iç tutarlılığı ölçmek için Cronbach Alfa katsayısı ve test yarılama yöntemi, kararlılığını ölçmek test-tekrar test korelasyonları hesaplanmış ve ayrıca madde analizi yapılmıştır.

\section{Bulgular}

\section{Geçerlik}

ÜÖUEMÖ’nin yapı geçerliğini test etmek amacı ile önce AFA, ardından DFA yapılmıştır.

\section{Açımlayıcı Faktör Analizi}

Katılımcıların ilk yarısı ile AFA çalışması gerçekleştirilmiştir. Çalışmada KMO değeri .88 bulunmuştur ve bu değer mükemmele yakın, iyi bir değer olarak yorumlanmaktadır (Büyüköztürk, 2010). Barlett Küresellik Testi'nin ise istatistiksel olarak anlamlı olduğu tespit edilmiştir $\left(\chi^{2}=5252\right.$, $\mathrm{p}=0.00)$. $\mathrm{Bu}$ sonuçlar verilerin faktör analizine uygun olduğunu göstermektedir. Maddelerin birbirleri ile olan korelasyon değerleri Tablo 3'te verilmiştir. 
Tablo 3: Maddeler ve Faktörler Arası Korelasyon Değerleri

\begin{tabular}{cccccccccc}
\hline Maddeler & M1 & M2 & M3 & M4 & M5 & M6 & M7 & M8 & Etkileşim \\
\hline M1 & 1.00 & & & & & & & & \\
M2 & .387 & 1.00 & & & & & & & \\
M3 & .415 & .387 & 1.00 & & & & & & \\
M4 & .362 & .524 & .362 & 1.00 & & & & & \\
M5 & .450 & .430 & .503 & .476 & 1.00 & & & & \\
M6 & .636 & .338 & .392 & .304 & .393 & 1.00 & & & \\
M7 & .456 & .255 & .252 & .248 & .281 & .519 & 1.00 & & \\
M8 & .591 & .360 & .357 & .359 & .400 & .628 & .486 & 1.00 & \\
Ulaşılabilirlik & & & & & & & & & .546 \\
\hline
\end{tabular}

Yapılan analizlerde maddelerin yapılan kuramsal çalışmalara uygun şekilde iki faktöre ayrılmış olduğu ve maddelerin her iki faktöre eşit olarak dağıldığı tespit edilmiştir. Faktörler toplam varyansın \%63.03'ünü açıklamıştır. İlk faktör olan etkileşim faktörü \%32.63, ikinci faktör olan ulaşılabilirlik faktörü ise \%30.40'1nı açılamıştır. Etkileşim boyutundaki maddelerin faktör yükleri .82 ile .73 aralığında, ulaşılabilirlik boyutundaki maddelerin faktör yükleri ise .78 ile .65 aralığındadır. Maddelerin hem ölçeğin geneli ile hem de kendi faktörleri ile gösterdikleri korelasyon değerleri de tabloda belirtilmiştir (Tablo 4).

Tablo 4: ÜÖUEMÖ’nin Faktör Yükleri Ve Düzeltilmiş Madde Toplam Korelasyonları

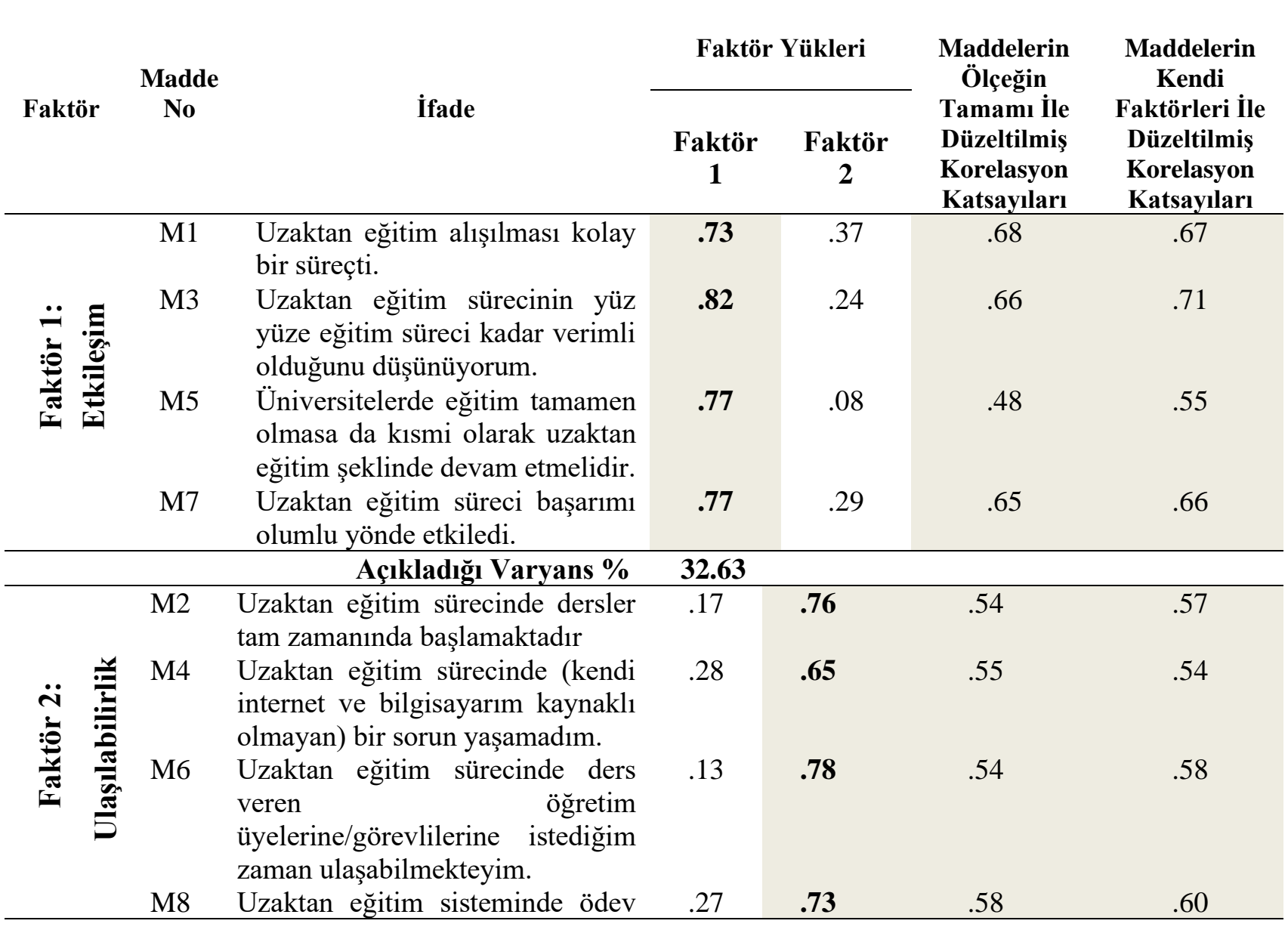




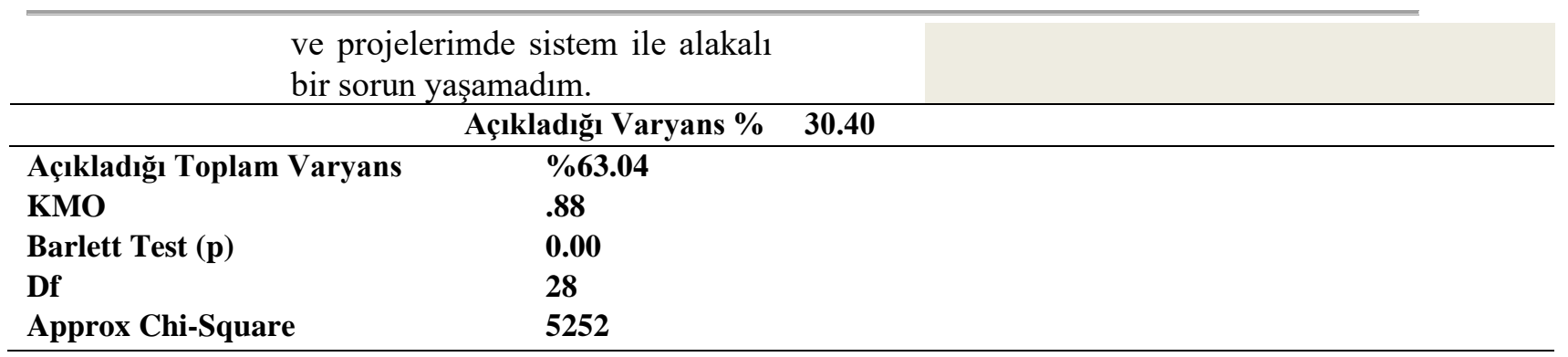

Not: Faktör Yükleri 0,30 üzerinde olanlar tabloda yazılmıştır.

\section{Alt Grup-Üst Grup Ortalama Farkı}

ÜÖUEMÖ yapı geçerliğine ilişkin ikinci kanıt ise, ölçek maddelerinin, alt boyutların ve ölçeğin genelinin ölçmeyi hedeflediği özelliği yüksek ve düşük düzeyde sahip olanlar arasında ne derece ayırt ettiğini belirlemek amacıyla yapılan analizinden elde edilmiştir. Katılımcıların ÜÖUEMÖ' den aldıkları toplam puanlar düşükten yükseğe doğru sıralanmıştır. Yapılan sıralama sonrasında alt ve üst \%27'lik gruplardan 990'ar olmak üzere 1980 kişi belirlenmiştir. Örneklem boyutu normallik varsayımını karşılamak için yeterli büyüklüktedir (Field, 2013). Ölçeğin her bir maddesinin, iki alt boyutunun ve ölçeğin genelinin bu iki grubu anlamlı düzeyde ayırt edip etmediğini belirlemek için T Testi kullanılmıştır ve sonuçlar Tablo 5'te verilmiştir.

Tablo 5: ÜÖUEMÖ’ nin Alt Boyutları ve Toplam Puanlarına Göre Oluşturulan Alt \%27 ve Üst \%27'lik Grupların Madde Ortalama Puanlarına Ait T Testi Sonuçları

\begin{tabular}{cccccccc}
\hline ÜÖUEMÖ & Gruplar & N & Ort. & S.S. & Min. & Max. & p \\
\hline Etkileşim 1 & Alt \%27 & 990 & 1.14 & .48 & 1 & 5 & .000 \\
& Üst \%27 & 990 & 3.34 & 1.28 & 1 & 5 & $*$ \\
\hline Etkileşim 2 & Alt \%27 & 990 & 1.04 & .32 & 1 & 5 & .000 \\
& Üst \%27 & 990 & 2.98 & 1.50 & 1 & 5 & $*$ \\
\hline Etkileşim 3 & Alt \%27 & 990 & 1.42 & .96 & 1 & 5 & .000 \\
& Üst \%27 & 990 & 3.87 & 1.30 & 1 & 5 & $*$ \\
\hline Etkileşim 4 & Alt \%27 & 990 & 1.21 & .59 & 1 & 5 & .000 \\
& Üst \%27 & 990 & 3.56 & 1.19 & 1 & 5 & $*$ \\
\hline Ulaşılabilirlik & Alt \%27 & 990 & 1.72 & .95 & 1 & 5 & .000 \\
$\mathbf{1}$ & Üst \%27 & 990 & 3.84 & .99 & 1 & 5 & $*$ \\
\hline Ulaşılabilirlik & Alt \%27 & 990 & 1.19 & .58 & 1 & 5 & .000 \\
$\mathbf{2}$ & Üst \%27 & 990 & 3.22 & 1.33 & 1 & 5 & $*$ \\
\hline Ulaşılabilirlik & Alt \%27 & 990 & 1.72 & .95 & 1 & 5 & .000 \\
$\mathbf{3}$ & Üst \%27 & 990 & 3.81 & .99 & 1 & 5 & $*$ \\
\hline Ulaşılabilirlik & Alt \%27 & 990 & 1.04 & .63 & 1 & 5 & .000 \\
$\mathbf{4}$ & Üst \%27 & 990 & 2.98 & 1.18 & 1 & 5 & $*$ \\
\hline Etkileşim & Alt \%27 & 990 & 4.15 & 0.35 & 4 & 5 & .000 \\
& Üst \%27 & 990 & 14.38 & 3.29 & 10 & 20 & $*$ \\
\hline Ulaşılabilirlik & Alt \%27 & 990 & 5.39 & 1.26 & 4 & 8 & .000 \\
& Üst \%27 & 990 & 15.41 & 2.21 & 13 & 20 & $*$ \\
\hline Toplam & Alt \%27 & 990 & 10.71 & 2.02 & 8 & 14 & .000 \\
(Etkileşim + & Üst \%27 & 990 & 28.63 & 5.37 & 22 & 40 & $*$ \\
Ulaşılabilirlik) & & & & & & & \\
\hline *p< $<01$ & & & & & & &
\end{tabular}


Sonuçlara bakıldığında ÜÖUEMÖ'nin geneli, boyutları ve tüm maddelerinin alt-üst gruplar arasında ortalama puan farkları $\mathrm{T}$ Testi ile karşılaştırıldı̆̆ında anlamlı çıkması $(\mathrm{p}<.01)$ ÜÖUEMÖ'nin genelinin, memnuniyet düzeylerini ayırt ettiği ve her bir sorusunun da katılımc1 düzeylerine uygun ölçümler yaptığı sonucuna ulaşılmıştır.

\section{Doğrulayıcı Faktör Analizi}

Katılımcıların ikinci yarısı ile DFA çalışması gerçekleştirildi. Çalışma doğrultusunda, AFA sonucunda elde edilen 8 madde ve iki faktörden oluşan yapının doğrulanıp doğrulamayacağ edildi. Analiz sırasında sırasıyla, etkileşim boyutuna ait olan 3. ve 2. maddeler, 1 . ve 4. maddeler ile ulaşılabilirlik boyutuna ait 2. ve 1. maddelerin hata terimleri bağlanmıştır. Buna göre etkileşim alt boyutundan "Uzaktan eğitim sürecinin yüz yüze eğitim süreci kadar verimli olduğunu düşünüyorum." ile "Üniversitelerde eğitim tamamen olmasa da kısmi olarak uzaktan eğitim şeklinde devam etmelidir" maddeleri ve "Uzaktan eğitim süreci başarımı olumlu yönde etkiledi." İle "Uzaktan eğitim alışılması kolay bir süreçti." maddelerinin hata terimleri bağlanmıştır. Ulaş1labilirlik alt boyutundan ise "Uzaktan eğitim sürecinde dersler tam zamanında başlamaktadır." ile "Uzaktan eğitim sürecinde (kendi internet ve bilgisayarım kaynakl olmayan) bir sorun yaşamadım." maddelerinin hata terimleri bağlanmıştır. Hata terimlerinin bağlanmasının sebebi, maddelerin içeriklerinin ve anlamlarının kendi aralarında birbirlerine yakın olmasıdır. Uyum iyiliği değerleri, bu değerlerin mükemmel ve kabul edilebilir değerleri ile beraber Tablo 6'da verilmiştir. Elde edilen veriler iki faktörlü modele sahip ölçeğin uyum iyiliği değerlerinin oldukça iyi olduğunu ortaya koymaktadır (Klein vd., 2016).

Tablo 6: Araştırmada İncelenen Uyum İndekslerine İlişkin Mükemmel ve Kabul Edilebilir Uyum Değerleri ile DFA'dan Elde Edilen Uyum İndeksi Değerleri

\begin{tabular}{|c|c|c|c|c|c|}
\hline $\begin{array}{l}\text { İncelenen } \\
\text { Uyum } \\
\text { İndeksleri }\end{array}$ & Kriterler & $\begin{array}{c}\text { Mükemmel } \\
\text { Uyum Ölçüttleri }\end{array}$ & $\begin{array}{c}\text { Kabul } \\
\text { Edilebilir } \\
\text { Uyum Ölçütleri }\end{array}$ & $\begin{array}{c}\text { Elde } \\
\text { Edilen } \\
\text { Uyum } \\
\text { İndeksleri }\end{array}$ & Sonuç \\
\hline$x^{2} / \mathbf{d f}$ & - & $x^{2} / \mathrm{df}<3$ & $3<x^{2} / \mathrm{df}<5$ & 2.92 & M.U.* \\
\hline GFI & $\begin{array}{c}0 \text { (uyum yok) } \\
1 \text { (mükemmel uyum) }\end{array}$ & $.95 \leq \mathrm{GFI} \leq 1.00$ & $.90 \leq \mathrm{GFI} \leq .95$ & .99 & M.U. \\
\hline AGFI & $\begin{array}{c}0 \text { (uyum yok) } \\
1 \text { (mükemmel uyum) }\end{array}$ & $.90 \leq \mathrm{AGFI} \leq 1.00$ & $.85 \leq \mathrm{AGFI} \leq .90$ & .99 & M.U. \\
\hline CFI & $\begin{array}{c}0 \text { (uyum yok) } \\
1 \text { (mükemmel uyum) }\end{array}$ & $95 \leq \mathrm{CFI} \leq 1.00$ & $.90 \leq \mathrm{CFI} \leq .95$ & 1.00 & M.U. \\
\hline NFI & $\begin{array}{c}0 \text { (uyum yok) } \\
1 \text { (mükemmel uyum) }\end{array}$ & $.95 \leq \mathrm{NFI} \leq 1.00$ & $.90 \leq \mathrm{NFI} \leq .95$ & .99 & M.U. \\
\hline NNFI & $\begin{array}{c}0 \text { (uyum yok) } \\
1 \text { (mükemmel uyum) }\end{array}$ & $95 \leq \mathrm{NNFI} \leq 1.00$ & $.90 \leq \mathrm{NNFI} \leq .95$ & .99 & M.U. \\
\hline IFI & $\begin{array}{c}0 \text { (uyum yok) } \\
1 \text { (mükemmel uyum) }\end{array}$ & $.95 \leq \mathrm{IFI} \leq 1.00$ & $.90 \leq \mathrm{IFI} \leq .95$ & 1.00 & M.U. \\
\hline PNFI & $\begin{array}{c}0 \text { (uyum yok) } \\
1 \text { (mükemmel uyum) }\end{array}$ & $.95 \leq \mathrm{PNFI} \leq 1.00$ & $.50 \leq \mathrm{PNFI} \leq .95$ & .57 & K.E.U.** \\
\hline RMSEA & $\begin{array}{c}0 \text { (mükemmel uyum) } \\
1 \text { (uyum yok) }\end{array}$ & $\begin{array}{c}.00 \leq \mathrm{RMSEA} \leq .0 \\
5\end{array}$ & $\begin{array}{c}.05 \leq \mathrm{RMSEA} \leq .0 \\
8\end{array}$ & .032 & M.U. \\
\hline SRMR & $\begin{array}{c}0 \text { (mükemmel uyum) } \\
1 \text { (uyum yok) }\end{array}$ & $.00 \leq \mathrm{SRMR} \leq .05$ & $.05 \leq \mathrm{SRMR} \leq .10$ & .018 & M.U. \\
\hline RMR & $\begin{array}{c}0 \text { (mükemmel uyum) } \\
1 \text { (uyum yok) }\end{array}$ & $.00 \leq \mathrm{RMR} \leq .05$ & $.05 \leq \mathrm{RMR} \leq .10$ & .034 & M.U. \\
\hline
\end{tabular}

$x^{2}=46.71 \quad$ RMSEA İçin \%95 Olasılıkla Güven Aralı̆̆ $1=(0.022 ; 0.043)$ 
*M.U.=Mükemmel Uyum, **K.E.U.=Kabul Edilebilir Uyum

DFA sonucunda elde edilen iki boyutlu modele ilişkin faktör yükleri Şekil 1'de yer almaktadır. Şekil 1'de görülebileceği gibi, faktör yükleri etkileşim boyutu için .54 ile .85 arasında ve ulaşılabilirlik boyutu için ise .74 ile .62 arasında değişmektedir.

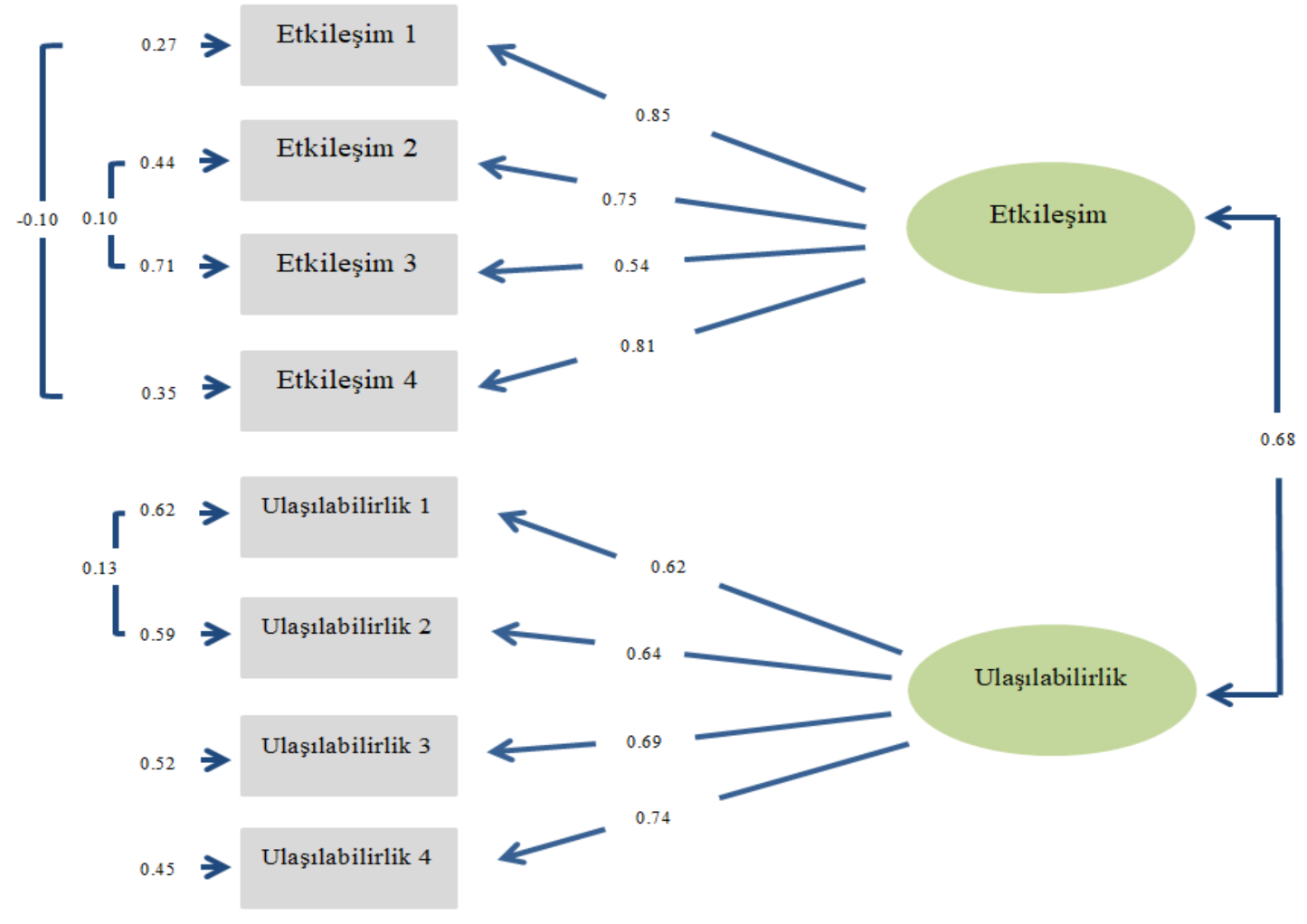

Şekil 1: ÜÖUEMÖ’ne İlişkin Ölçüm Modeli

Tablo 7: Maddelerin AFA ve DFA Sonucu Elde Edilen Madde Yüklerinin Karşılaştırılması

\begin{tabular}{ccccccccc}
\hline & Etkileşim & Etkileşim & Etkileşim & Etkileşim & Ulaşılabilirlik & Ulaşılabilirlik & Ulaşıిlabilirlik & Ulaşılabilirlik \\
& $\mathbf{1}$ & $\mathbf{2}$ & $\mathbf{3}$ & $\mathbf{4}$ & $\mathbf{1}$ & $\mathbf{2}$ & $\mathbf{3}$ & $\mathbf{4}$ \\
\hline AFA & .73 & .82 & .77 & .77 & .76 & .65 & .78 & .73 \\
DFA & .85 & .75 & .54 & .81 & .62 & .64 & .69 & .74 \\
\hline
\end{tabular}

AFA ve DFA sonucu elde edilen faktör yüklerinin karşılaştırılması Tablo 7'de verilmiştir. Her iki analiz sonucu paralel olup maddeler uygun değerde (>.30) faktör yüklerine sahiptir (Aksu vd. 2017).

\section{Güvenirlik}

ÜÖUEMÖ’nin güvenirliği iç tutarlılık kapsamında madde analizi, Cronbach Alfa katsayısı ve test yarılama tekniğ i ile incelenirken kararlılığı test tekrar test yöntemi ile incelenmiştir. Cronbach Alfa katsayıları incelenirken hem AFA için ayrılan, hem DFA için ayrılan hem de genel örneklem üzerinde analiz gerçekleştirilmiştir. Sonuçlar Tablo 8'de verilmiştir. 
Tablo 8: ÜÖUEMÖ’nin ve Boyutlarının Farklı Örneklem Gruplarında Cronbach Alfa Güvenirlik Katsayıları

\begin{tabular}{cccc}
\hline & \multicolumn{3}{c}{ Faktörler } \\
\hline & Etkileşim & Ulaşılabilirlik & ÜÖUEMÖ \\
\hline $\begin{array}{c}\text { AFA Grubu İçin } \\
\text { Cronbach Alfa }\end{array}$ & .82 & .76 & .84 \\
\hline $\begin{array}{c}\text { DFA Grubu İçin } \\
\text { Cronbach Alfa }\end{array}$ & .81 & .78 & .85 \\
\hline $\begin{array}{c}\text { Genel Örneklem İçin } \\
\text { Cronbach Alfa }\end{array}$ & .82 & .77 & .85 \\
\hline
\end{tabular}

Sonuçları incelediğimizde genel örneklem verilerinde .80 değerinin üzerinde olan ölçeğin genelinin ve etkileşim boyutunun Cronbach Alfa değerini yüksek derecede güvenilir, .80 değerine yakın olan ulaşılabilirlik boyutunun da yüksek güvenirliğe yakın olduğunu söyleyebiliriz. Aynı durum AFA ve DFA analizi örneklem grupları için de geçerlidir (Özdamar, 1997; Kalayc1, 2008; Aksu vd., 2017).

Testin iç tutarlılığına dair başka güvenirlik kanıtı elde edebilmesi için testi yarılama yöntemi, kararlılığına dair kanıt elde edilebilmesi için de test yarılama tekniği kullanılmıştır. Test yarılama yöntemi uygulanırken yarıların varyansı eşit olmadığında dolayı güvenirlik katsayısı hesaplamasında Guttman Formülü'nden yararlanılmıştır (Soğuksu \& Alıc1, 2016, s. 240). Buna göre güvenirlik katsayısı 0.87 olarak hesaplanmıştır. Test tekrar test sonuçları da paralel şekilde yüksek güvenilir çıkmıştır. Son olarak güvenirlik kanıtı sağlamak amacı ile madde analizi yapılmıştır. Bu kapsamda yapılan alt-üst grup analizi sonuçları Tablo 4'te ve madde korelasyon katsayıları da Tablo 3'te belirtilmiştir. Madde analizine ait diğer sonuçlar Tablo 9'da gösterilmiştir.

Tablo 9: Madde Analizi Sonuçları

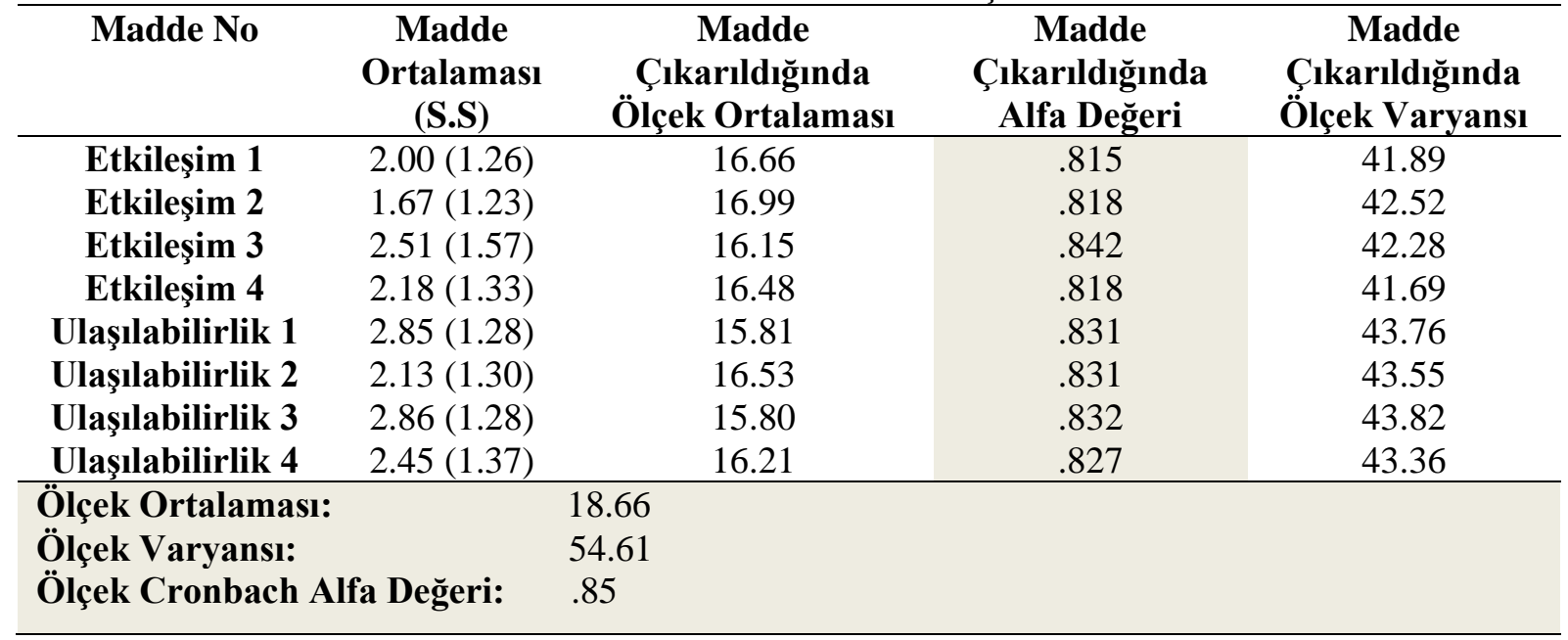

Sonuçlardan yola çıkarak, eğer maddelerden herhangi birisinin ölçekten çıkarılması durumunda, ölçeğin Cronbach Alfa değeri düştüğü görülmektedir. Bu da güvenilir bir ölçek için beklenen bir durumdur. Ölçeğin güvenirliğini olumsuz yönde etkileyen bir maddenin olmadığının göstermektedir.

\section{Tartışma}

Günümüzde özellikle Covid-19 küresel pandemi döneminde eğitim sektörü çok hızlı bir şekilde uzaktan eğitime geçiş yaptı. Bu çalışmada üniversite öğrencilerinin uzaktan eğitim 
sisteminden memnuniyetine ilişkin ölçüm elde edebilmeyi amaçlayan geçerli ve güvenilir bir araç geliştirilmek amaçlanmıştır. Uzaktan eğitimde iletişim ve etkileşim kuramı temelinde geliştirilen ölçek, öğrencilerin memnuniyetini bireysel, eğitsel ve yönetsel merkezli olarak ölçüm yapmayı amaçlamaktadır (Gökmen vd., 2016, s. 37). Hazırlanan ölçek, kuram kavramlarına paralel şekilde "etkileşim" ve "ulaşılabilirlik" boyutlarından oluşmaktadır.

Uzaktan eğitimde etkileşim ve ulaşılabilirlik kavramları öğrencilerin memnuniyeti açısından önem arz etmektedir. Belirli öğrenim hedeflerine yönelik planlamalar yapılırken eğitim veren ile alan kişilerin iletişiminin yani etkileşiminin ön planda olması önemlidir. (Keegan, 1996). $\mathrm{Bu}$ etkileşim eğitimi alan kişinin motivasyon sağlaması, çalışmaya başlaması, ihtiyaçlarını karşılaması ve memnuniyetinin artması açısından önemlidir. (Gökmen vd. 2016, s. 33). Etkileşimin sağlanması, öğrenmeden zevk alınması, motivasyon, öğrenmeyi kolaylaştırma ve öğrenilenlerin aktarılması gibi unsurlar olduğunu belirterek bu unsurların birbirlerini tetiklemesiyle memnuniyetin artacağı ifade etmektedir (Keegan, 1996). Dahası bu etkileşimin sorunsuz bir şekilde ulaşılabilir olması da memnuniyeti arttırıcı bir faktördür.

COVID-19 pandemisi döneminde uzaktan eğitime acil geçiş yapılması, öğrencilerin eğitim sisteminden memnuniyeti hakkında geri bildirim elde edebilmeyi önemli hale getirmiştir. Bu geri bildirimler sayesinde sistemin hangi konularda revize edileceği saptanmaktadır. Uzaktan eğitim memnuniyeti çok yönlü bir kavramdır. Etkileşim ve iletişim kuramına göre uzaktan eğitim memnuniyetinin bazı yönlerini aydınlatabiliriz. Bu çerçevede oluşturulan ölçek maddelerinden etkileşim boyutuna dahil olan maddeler, öğrenci memnuniyetinde etkileşim kavramı göz önüne alınarak oluşturulmuştur. Örneğin uzaktan eğitimin yüzyüze eğitim kadar verimli olduğu konusundaki madde öğrencilerin motivasyonu ve memnuniyeti açısından önemli bir konudur. Çünkü madde uzaktan eğitimde eğitmen, ders materyalleri gibi öğelerle eğitimi alan kişiler arasındaki etkileşimin düzeyini ölçmektedir. Ulaşılabilirlik alt boyutundaki eğitim alan kişilerin eğitmenlere istedikleri zaman ulaşabildiği, sistemsel sorunların yaşanması gibi maddeler de uzaktan eğitimin erişilebilirlik düzeyi hakkında bilgi sağlamaktadır.

Tüm bunlar göz önüne alındığında etkileşimin ve ulaşılabilirliğin uzaktan eğitim sisteminden memnuniyet düzeyini etkilediğini söyleyebilir. Bu kavramlardan birinin eksik kalmasi memnuniyet düzeyini düşürebilir. Nitekim uzaktan eğitimde eğitmen, ders materyalleri gibi önemli unsurlarla etkileşimin eksikliği, sisteme ulaşılabilirlik her ne kadar yüksek düzeyde olsa da, eğitimi alan kişilerde motivasyon kaybına, başarı düşüklüğüne doalyısıyla da memnuniyet düzeyinin düşüklüğüne yol açar. Tam tersi şekilde aktif bir etkileşim olmasında rağmen sistemin ulaşilabilir olmaması ve sürekli altyapı sorunları gibi sorunlar çıkarması da memnuniyet düzeyini düşürebilir.

\section{Sonuç}

Türk literatürü incelendiğinde uzaktan eğitimden memnuniyeti ölçmek amacı ile kullanılabilecek sınırlı sayıda çalışma tespit edilmiştir. Uzaktan eğitimde iletişim ve etkileşim kuramı temelinde geliştirilen bir ölçeğe ise rastlanamamıştır. ÜÖ̈UEMÖ'nin geliştirilmesinin amaçlandığı bu çalışma literatürde bulunan söz konusu boşluğu dolduracak olması açısından önemlidir. Bir başka deyişle, etkileşim ve iletişim temelli olarak uzaktan eğitimden memnuniyet ile ilgili Araştırmanın güçlü yönlerinden birisi, konu hakkında Türkçe literatürde adım atılmasını sağlamasıdır. Araştırmada ÜOUEMÖ'den elde edilen ölçümlerin ölçek maddelerinin ayırt ediciliği, geçerlik ve güvenirliği ile ilgili birden fazla kanıt sunulması da çalışmanın güçlü yönleri arasındadır. Örneğin, ölçümlerin güvenirliğinin incelenmesinde Cronbach Alfa, test yarılama ve test tekrar test güvenirlik katsayılarından yararlanılmıştır. Cronbach Alfa ve test yarılama katsayıları ile ölçümlerin tutarlılık anlamında güvenirliğini incelerken, test tekrar test güvenirlik katsayısı ölçümlerin kararlılık anlamında güvenirliği incelenmiştir. Ölçek maddelerinin ayırt ediciliğini ortaya koymak için hem maddelerin kendi faktörleri ile hem de ölçeğin geneli ile düzeltmiş madde toplam korelasyonuyla birlikte, \%27'lik alt üst grup karşılaştırmalarına da yer 
verilmiş̧ir. Bu sayede ölçek hem genel toplam puan ile hem de faktörlerine ait toplam puanlar ile değerlendirilebilecektir. Ölçümlerden yapılan yorumların yapı geçerliği için hem AFA hem de DFA uygulanmıştır.

\section{Sinırlılıklar}

Çalışmanın güçlü yönlerinin yanında bir takım sınırlılıkları da mevcuttur. Çalışmanın en önemli sınırlılığ 1 , çalışmanın sadece üniversite öğrencileri örnekleminde yürütülmüş olmasıdır. Gelecek çalışmaların farklı örneklem grupları (ilköğretim ve lise öğrencileri) üzerinde yapılması önem arz etmektedir. Bir başka sınırlılı̆ğ ise, literatür incelendiğinde etkileșim ve iletișim kuramı temelinde çalışmanın, memnuniyetin bireysel, eğitsel ve yönetsel yönleri temelinde çalışma geliştirilebilir. Son olarak araştırmanın bir diğer sınırlılığı ise, az madde ile etkili ölçüm yapılabilmesi adına, araştırma başında madde havuzu, ölçekte hedeflenen soru sayısının 2 katı ile sınırlı tutulmuştur. Madde havuzu daha geniş hazırlanarak araştırmaya başlanabilirdi. Bununla birlikte ölçeğin şu anki halinin, faktör ve madde analizleri göz önüne alındığında etkili bir ölçüm yapabileceği düşünülmektedir.

\section{Kaynakça}

Aksu, G., Eser, M. T. \& Güzeller, C. O. (2017). Açımlayıcı ve doğrulayıcı faktör analizi ile yapısal eşitlik modeli uygulamaları, Detay Yayıncılık.

Aktepe, C., Baş, M. \& Tolon, M. (2009). Müşteri ilişkileri yönetimi. Detay Yayıncılık.

Ansari, W. E. (2002). Student nurse satisfaction levels with their courses: Part I effects of demographic variables. Nursing Education Today, 22(2), 159-169. https://doi.org/10.1054/nedt.2001.0682.

Baykal, Ü. \& Şahin, A. (1999). Toplam kalite yönetimi ve eğitimde toplam kalite. Hemşirelik Bülteni, 45, 123-137

Baykal, Ü., Sökmen S., Korkmaz, Ş. \& Akgün, E. (2002). "Öğrenci memnuniyeti ölçeği”" geliştirme çalışması. Hemşirelik Dergisi, 11(49), 23-32.

Büyüköztürk, Ş. (2010). Sosyal bilimler için veri analizi el kitabı. Pegem Akademi Yayınları.

Elliott, K.M. \& Shin, D. (2002) Student satisfaction: An alternative approach to assessing this important concept. Journal of Higher Education, Policy and Management, 24(2), 197 -209. https://doi.org/10.1080/1360080022000013518

Erdoğan, M. \& Uşak, M. (2005). Fen bilgisi öğretmen adayları memnuniyet ölçeğinin geliştirilmesi. Gazi Eğitim Fakültesi Dergisi, 25(2), 35-54.

Erdoğan, M. \& Uşak, M. (2004). Factors affecting prospective science teacher satisfaction level on their department. (Abstract) Paper presented at the conference of Earli' Jure, July 2004, İstanbul: Bahçeşehir Üniversitesi.

Field, A. (2013). Discovering statistics using IBM SPSS statistics (4. Bs.). Sage Publication, 318 417.

Gatfield, T., Barker, M. \& Graham, P. (1999). Measuring student quality variables and the implications for management practices in higher education institutions: An Australian and international student perspective. Journal of Higher Education Policy \& Management, 21(2), 239 - 255. https://doi.org/10.1080/1360080990210210

Gökmen, Ö. F., Duman, İ. \& Horzum, M. B. (2016). Uzaktan eğitimde kuramlar, değişimler ve yeni yönelimler. Açıköğretim Uygulamaları ve Araştırmaları Dergisi, 2(3), 29-51. 
Guolla, M. (1999). Assessing the teaching quality to student satisfaction relationship: Applied customer satisfaction research in the classroom. Journal Of Marketing Theory And Practice, 7(3), 87-97. https://doi.org/10.1080/10696679.1999.11501843

Kalaycı, Ş. (2008). SPSS uygulamalı çok değişkenli istatistik teknikleri (3.bs.). Asil Yayın Dağıtım.

Kantoğlu, B., Torkul, O. \& Altunışık, R. (2013). E-öğrenmede öğrenci memnuniyetini etkileyen faktörlerin incelenmesine yönelik model önerisi. Business and Economics Research Journal, 4(2), 121-141.

Keegan, D. (1996). Foundation of Distance Education. (3. Bask1). Routledge

Kışla, T. (2016). Uzaktan eğitime yönelik tutum ölçeği geliştirme çalışması. Ege Eğitim Dergisi, 17(1), 258-271. https://doi.org/10.12984/eed.01675

Klein, J. P., Van Houwelingen, H. C., Ibrahim, J. G., \& Scheike, T. H. (Eds.). (2016). Handbook of survival analysis. CRC Press.

Kocadere, S.A. (2013). Çevrimiçi öğrenme ortamlarında öğrenen memnuniyeti. Ulusal Uzaktan Eğitim ve Teknolojileri Sempozyumu 1-3 Kasım 2013, Konya: Selçuk Üniversitesi.

Kümbetoğlu, B. (2012). Sosyolojide ve Antropolojide Niteliksel Yöntem ve Araştırma (3. Bask1), Bağlam Yayıncılık.

Lamport, M. A. (1993). Student-Faculty informal interaction and the effect on college student outcomes: A Review of the literature. Adolescence, 28(112), 971- 991.

Oğuz, A. (2002) Üniversitelerdeki öğretim elemanlarının yabancı dili geliştirme, Eğitim ve Bilim, $27(125), 17-26$.

Özdamar, K. (1997). Paket programlar ve istatistiksel veri analizi. Anadolu Üniversitesi Yayınları.

Pallant, J. (2005). SPSS survival manual: A step by step guide to data analysis using SPSS for windows. Australian Copyright.

Parlak, Ö. (2007). İnternet temelli uzaktan eğitimde öğrenci doyumu ölçeği. Eğitim Bilimleri ve Uygulama Dergisi, 6(11), 53-72.

Srikanthan, G. \& Dalrymple, J.F. (2002). Developing a holistic model for quality in higher education. Quality in Higher Education, 8(3), 215-224. https://doi.org/10.1080/1353832022000031656

Student Life Studies (1999). Evidence of the quality and effectiveness of undergraduate education at the University of Missouri Colombia. http://www.missouri.edu/ wwwsls/education.html adresinden erişildi.

Soğuksu, Y. \& Alıcı, D. (2016). Eşdeğer yarılar güvenirliğinin farklı homojenlik düzeylerindeki örneklem büyüklüklerinde, test uzunluğuna, yarıya bölme yöntemlerine ve güvenirlik kestirme tekniklerine göre incelenmesi. Mersin Üniversitesi Eğitim Fakültesi Dergisi, 237-252. http://dx.doi.org/10.17860/efd.64335.

Sun, P. C., Tsai, R. J., Finger, G., Chen, Y. Y. \& Yeh, D. (2008). What drives a successful eLearning? An empirical investigation of the critical factors influencing learner satisfaction. Computers \& Education, 50(4), 1183-1202. https://doi.org/10.1016/j.compedu.2006.11.007 
Şimşek, H., İslim, Ö. \& Öztürk, N . (2019). Yükseköğretimde kalite arayışında bir gösterge olarak öğrenci memnuniyeti: Bir ölçek geliştirme çalışması. Trakya Eğitim Dergisi, 9(3) , 380-395. $10.24315 /$ tred.441397.

Tessema, M.T., Ready, K. \& Yu, W. W. (2012). Factors affecting college students' satisfaction with major curriculum: Evidence from nine years of data. International Journal of Humanities and Social Science, 2(2), 34-44.

Tütüncü, Ö. \& Doğan, Ö. İ. (2003). Müşteri tatmini kapsamında öğrenci memnuniyetinin ölçülmesi ve Dokuz Eylül Üniversitesi, Sosyal Bilimler Enstitüsü uygulaması. Dokuz Eylül Üniversitesi Sosyal Bilimler Enstitüsü Dergisi, 5(4), 130-151.

Ulusoy H., Arslan Ç., Öztürk N. \& Bekar M. (2010). Hemşirelik öğrencilerinin eğitimleriyle ilgili memnuniyet düzeylerinin saptanması. Maltepe Üniversitesi Hemşirelik Bilim ve Sanatı Dergisi, 3(2), 15-24.

Wilson, R.C., Gaff, J.G., Dienst, E.R., Wood, L. \& Bavry, J.L. (1975). College professors and their impact on students. Willey.

Wilson, R.C., \& Gaff, J.G. (1975). College professors and their impact on students. John Wiley \& Sons.

Yıldırım, S., Yıldırım, G., Çelik, E., \& Karaman, S. (2014). Uzaktan eğitim öğrencilerinin uzaktan eğitime yönelik görüşleri: Bir ölçek geliştirme çalışması. Eğitim ve Öğretim Araştırmaları Dergisi, 3(3), 365-370. 


\section{Ek. Üniversite Öğrencilerinin Uzaktan Eğitim Memnuniyeti Ölçeği}

\begin{tabular}{|c|c|c|c|c|c|c|}
\hline \multicolumn{7}{|c|}{ Üniversite Öğrencilerinin Uzaktan Eğitim Memnuniyeti Ölçeği } \\
\hline \multicolumn{7}{|c|}{$\begin{array}{l}\text { Aşağıda çeşitli durumlara ilişkin ifadeler bulunmaktadır. Her maddeyi dikkatlice okuduktan sonra size en } \\
\text { uygun gelen seçeneği işaretleyiniz. }\end{array}$} \\
\hline 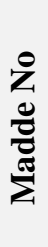 & Maddeler & 总 & 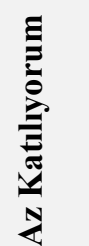 & 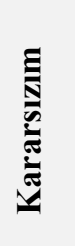 & 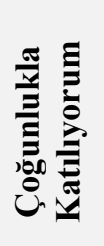 & 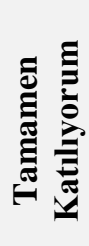 \\
\hline 1 & Uzaktan eğitim alışılması kolay bir süreçti. & (1) & (2) & (3) & (4) & (5) \\
\hline 2 & $\begin{array}{l}\text { Uzaktan eğitim sürecinin yüz yüze eğitim süreci kadar } \\
\text { verimli olduğunu düşünüyorum. }\end{array}$ & (1) & (2) & (3) & (4) & (5) \\
\hline 3 & $\begin{array}{l}\text { Üniversitelerde eğitim tamamen olmasa da kısmi olarak } \\
\text { uzaktan eğitim şeklinde devam etmelidir. }\end{array}$ & (1) & (2) & (3) & (4) & (5) \\
\hline 4 & Uzaktan eğitim süreci başarımı olumlu yönde etkiledi. & (1) & (2) & (3) & (4) & (5) \\
\hline 5 & $\begin{array}{l}\text { Uzaktan eğitim sürecinde dersler tam zamanında } \\
\text { başlamaktadır. }\end{array}$ & (1) & (2) & (3) & (4) & (5) \\
\hline 6 & $\begin{array}{l}\text { Uzaktan eğitim sürecinde (kendi internet ve bilgisayarım } \\
\text { kaynaklı olmayan) bir sorun yaşamadım. }\end{array}$ & (1) & (2) & (3) & (4) & (5) \\
\hline 7 & 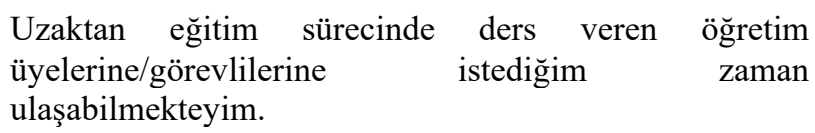 & (1) & (2) & (3) & (4) & (5) \\
\hline 8 & $\begin{array}{l}\text { Uzaktan eğitim sisteminde ödev ve projelerimde sistem } \\
\text { ile alakalı bir sorun yaşamadım. }\end{array}$ & (1) & (2) & (3) & (4) & (5) \\
\hline
\end{tabular}

Açıklama: Ölçek beşli likert tipindedir. Ölçekte ters madde bulunmamaktadır. Alınan toplam puan arttıkça memnuniyet düzeyinin de arttığı düşünülmelidir.

\section{Beyan ve Açıklamalar (Disclosure Statements)}

1. Araştırmacıların katkı oranı beyanı / Contribution rate statement of researchers:

1. Yazar/First author $\% 50$,

2. Yazar/Second author $\% 50$,

2. Yazarlar tarafından herhangi bir çıkar çatışması beyan edilmemiştir (No potential conflict of interest was reported by the authors). 